\title{
The Notion of Good and Bad Governance in Comparative Perspective*
}

\author{
Bert A. Rockman** and Sung Deuk Hahm***
}

\begin{abstract}
A governance crisis may not only be detrimental to public trust of the government, but can also be a source of economic stagnation and social instability. Good and bad governance has become an indispensable line of research in public management. Scholars and practitioners in public management are concerned about what makes some government institutions better than others. This paper first explores the theoretical evolution of the term "governance" as distinct from "government." Second, it sorts out factors related to definitions and measurements of good and bad governance in comparative perspective based on two competing theoretical frameworks for understanding these concepts: principles and consequences. Third, it provides criteria for the notion of good and bad governance and argues that it is multidimensional, continuous rather than discrete, conditional, consequential, and empirical as well as philosophical. Finally, this paper identifies emerging challenges and opportunities for advancing understanding of good and bad governance.
\end{abstract}

Keywords: governance crisis, good governance, bad governance, public management

\section{INTRODUCTION}

Contrary to conventional wisdom, which suggests that a governance crisis is more likely to occur in least developed or transitional countries where political stability and social and economic maturity are rarely found, a governance crisis can also occur in

* This study was supported by the National Research Foundation of Korea grant funded by the Korean government (NRF-2010-330-B00031). Address correspondence to Sung Deuk Hahm, Department of Public Administration, Korea University, 5-1 Anamdong, Sungbukku, Seoul 136-701, South Korea.

** Bert A. Rockman is professor and head of the political science department at Purdue University. E-mail: barockma@purdue.edu.

*** Sung Deuk Hahm is professor of political economy at Korea University. E-mail: hahm33@ hotmail.com.

Manuscript received June 20, 2011; out for review June 23, 2011; review completed August 3, 2011; accepted August 10, 2011.

The Korean Journal of Policy Studies, Vol. 26, No. 2 (2011), pp. 1-16.

(C) 2011 by the GSPA, Seoul National University 
politically, economically, and socially developed countries. Such a crisis may not only be detrimental to public trust of the government but can also be a source of economic stagnation and social instability.

In this regard, good governance has become an indispensable line of research in public management, because scholars and practitioners in public management are concerned about what makes some government institutions work better than others (Rothstein \& Teorell, 2008a). In particular, they analyze government performance or effectiveness in order to uncover ways of producing good governance (Whitford \& Lee, 2009). Many recent government reform efforts across countries have focused on improving government performance or effectiveness in the public sector for good governance (Rosenbloom \& Hahm, 2010).

The notion of good and bad governance has received wide attention in many countries. In particular, the notion of what constitutes good or bad governance is contested and multidimensional and an important topic too often overlooked. Good and bad governments are products of the quality of decisions and actions by public officials and enhance the trust of the public in the polity and its leaders. The latter, especially, signifies the importance of a nexus between the state and civic society. A governance crisis can emerge from the tensions in and deterioration of such a nexus.

In this new environment, theoretical research on good and bad governance builds on prior research by tapping some new data sources to undertake a comparative examination of measures of good and bad governance and some closely related governance metrics such as political stability, rule of law, regulatory quality, government effectiveness, and transparency (Brewer, Choi, \& Walker, 2007; Kaufman, Kraay, \& Mastruzzi, 2006; Whitford \& Lee, 2009). ${ }^{1}$ This theoretical research on good and bad governance usually focuses on three aspects: how to define good and bad governance, how to measure it, and what factors influence it.

In this context, this paper first explores the theoretical evolution of the term "governance" (as distinct from "government") as a basis for understanding the notion of good and bad governance. Second, it sorts out factors related to definitions and measurements of good and bad governance in comparative perspective based on two competing theoretical frameworks of the notion of good and bad governance:

1. These previous studies were limited in that they assessed the good and bad performance of one government agency or of several government agencies within one country. Few studies have assessed good and bad governance in an entire government or compared good and bad governments across many countries (Whitford \& Lee, 2009). Therefore, a comparative analysis of variation in good and bad government across countries gives us a better understanding of governance crisis in public administration and management. 
principles and consequences. Third, it provides criteria for evaluating good and bad governance and argues that it is multidimensional, continuous rather than discrete, conditional, consequential, and empirical as well as philosophical. Finally, the paper identifies emerging challenges and opportunities for advancing understanding of good and bad governance.

\section{THEORETICAL EVOLUTION OF "GOVERNANCE"}

It is important to look at the theoretical evolution of the term "governance" as applied to the public sector, what it has come to mean, and why it has become so widely used as distinct from the term "government," in order to understand the notion of good and bad governance in depth. Furthermore, examining differences between governance and government helps us to understand features of current governance crises across countries.

Kettl (1995, p. 27) argues that governance involves an understanding of the complexity of the relationships, interrelationships, and interdependencies (between the state and others) as important determinants of how well the government works. Kaufmann, Kraay, and Mastruzzi (2004, p. 3) define governance as the traditions and institutions by which authority in a country is exercised. Specifically, it includes the process by which governments are selected, monitored, and replaced; the capacity of the government to formulate and implement sound policies effectively; and the respect of citizens and the state for the institutions that govern economic and social interactions among them. However, these definitions of governance are too broad and fail to distinguish between various institutional particulars and basic principles.

In this regard, Longo (2008, p. 194) defines governance as a set of institutional arrangements that are used to adopt and implement public decisions. It embraces structures, processes, players and their interrelationships, rules, control, enforcement and accountability mechanisms, incentives, and in general all elements bearing on decisions in the public sphere. Longo (2008, p. 192) further argues that governance is characterized by the relational nature of the public sphere in dealing with difficult emerging issues, which require increasing coordination and collaboration on the part of government. The need is for joined-up, holistic governments, whole-of-government approaches, interagency collaboration, and-beyond the government sphere-for a network in which public agencies play multiple roles (regulating, designing, financing, controlling, promoting, steering, supporting, and partnering), depending on the context and the public policies required.

Therefore, although good government lies at the core of good governance, the two 
concepts should be clearly distinguished. Each has its distinctive mode of politics and policy formation. The coverage of governance (the so-called public sphere) is much wider than that of government (the so-called state sphere), for it is conterminous with that of the modern state (see Longo, 2008; Power, 2007). In practice, Kettl (1995, p. 31) argues, governance encompasses a far larger view of government and of the other institutions that government relates to that enable public work to take place.

Moreover, Kettl (1995, p. 28) explains the new role of government in the world of governance. He argues that the old-concept government primarily performed the role of delivering services. It extinguished fires, arrested criminals, cured poverty, provided health care, and did what it needed to do, primarily by itself. In contrast, a government in the world of governance acts primarily as a catalyst. It doesn't necessarily do anything itself, but it makes sure that things get done.

In this context, governance can be defined as the capacity of government to steer the economy and society and the process of providing direction to society (Peters \& Pierre, 2002). In sum, government exists in a governance system that is increasingly interdependent (Kettl, 1995, pp. 27, 39). However, this paper will use good and bad government and good and bad governance to mean the same thing, for the convenience of discussion.

\section{LITERATURE ON THE DEFINITION OF GOOD AND BAD GOVERNANCE}

What is "good government"? Is it transparent, responsive, small and unobtrusive, or on the contrary, big and active? And is "good government" the same everywhere, or do regional differences of opinion have to be acknowledged?

Helgesen \& Kim, 2002, p. 1

\section{Importance of Subjective Factors}

What is good governance? And, conversely, what is bad governance? These seemingly simple questions have puzzled and perhaps even boggled many minds-certainly ones far superior to our own. It is hard to imagine questions of more fundamental significance than these. Undoubtedly, how we perceive good and bad governance is conditioned by a number of highly subjective experiences and values.

First among these subjective factors are our personal values or ideological frames of reference or, as economists like to put it, our priors (Rosenbloom, Kravchuk, \& Clerkin, 2009). Second are our cultural norms-how we collectively define what is 
right and wrong (March \& Olsen, 1989; Rosenbloom, 1993). Third is our collective past, which is defined in terms of which collective happens to be dominant in our past. Heterogeneity increases the mix of past experiences and potentially the difficulty of sharing common ones.

A fourth subjective factor may have to do with our collective state of social development. Good and bad governance may mean different things depending on where we are developmentally. If, for example, the theories of Ronald Inglehart $(1971,1977)$ about value hierarchies are accurate, what is valued and perhaps perceived as good at one stage may be perceived as bad at another-for example, rampant development vs. green values and social justice.

A fifth subjective factor is no doubt shaped by who our peers are. For example, the logic of economics runs counter to the practices of rent-seeking, log-rolling (vote trading), pork-barreling (excessive advocacy for government spending for the district one represents), and the protection of tastes that have little market leverage. But if one's peers are political scientists, such practices will seem to fall under the cost of doing business (transaction costs) and will therefore appear to be highly rational. Discussions of good and bad governance have been dominated until now by political philosophers and by economists who fail to notice that they, themselves, are political philosophers.

\section{Importance of an Empirical Approach}

There is now a growing body of empirical literature trying to capture the inner core of good governance (Brewer, 2004; Brewer, Choi, \& Walker, 2007; La Porta, Lopezde-Silanes, Shleifer, \& Vishny, 1999; Rauch \& Evans, 2000; Rothstein \& Teorell, 2008a; Whitford \& Lee, 2009; Wong \& Welch, 2004). For example, the World Bank's worldwide indicators for good governance cover 213 countries and territories and measure six dimensions of governance from 1996 until 2005: voice and accountability, political stability and absence of violence, government effectiveness, regulatory quality, rule of law, and control of corruption (Kaufman, Kraay, \& Mastruzzi, 2006).

There are, however, a series of basic questions. First, distinguishing good governance from bad governance is challenge enough. That is the definitional problem. If it rests exclusively upon subjective factors, we will never be able to reach agreement. If, on the other hand, empirical research can help us discover some universals, we at least can get to the starting gate. In other words, we need to rely on both political philosophy and empirical inquiry to have a chance even to begin analysis of the question. Alone, neither may get us very far.

After all, empirical discovery without theoretical grounding has no logical coherence, whereas theoretical grounding without empirical discovery lacks validity. In this 
regard, Peters $(2003$, p. 1) argues that empirical evidence is necessary in order to consider how governments perform their tasks and do (or do not) govern their societies. On the other hand, governance is also inherently a normative concern. Therefore, the analysis of the notion of good governance should be both empirical and normative.

With regard to the importance of an empirical approach to the definition of good governance, Alesina and Angeletos (2005, p. 18) find that a large government increases corruption and rent-seeking. This empirical finding implies that if one wants to improve the quality of governance, one should lower policy ambitions, especially when it comes to redistributive policies. In other words, it suggests that the way to enhance the quality of government is simply to shrink its size; small government is synonymous with aspects of good government such as the absence of corruption.

However, La Porta, Lopez-de-Silanes, Shleifer, and Vishny (1999) argue, based on empirical data from 212 countries, that the size of government has little or nothing to do with the quality of government. Moreover, they (1999 p. 266) conclude that betterperforming governments are larger and collect higher taxes, while poorly performing governments are smaller and collect fewer taxes. Rothstein and Teorell (2008a) also find that Alesina and Angeletos's (2005) argument is empirically false: governments with very low levels of corruption are relatively large-scale, as the examples of Scandinavia, the Netherlands, and the United Kingdom illustrate.

Furthermore, Rothstein and Teorell (2008a, 2008b) have engaged in a systematic comparative analysis of quality of government to get to the heart of good governance by focusing on the irreducibility of fairness (impartiality) as an empirical result. Another point of view, represented by Longo (2008), emphasizes the importance of context and the minimalist character of universals. The presumption is that fairness is insufficient — hardly a new argument—but inevitably raises the question of compensatory equity, which produces, for whatever it is worth, controversy and resentment. Wilson (2008) stresses the motives and character of decision-makers-whether or not they are driven to do good or, less happily, simply to do well (for themselves). Specifically, Wilson (2008) emphasizes the necessity of trade-offs between highly desirable goals and the importance of experienced, knowledgeable, and disciplined decisionmakers able to assess these in a careful way. He equally emphasizes the limits of preordained rules.

\section{Principles vs. Consequences}

Considering the complexity of these theoretical arguments, we could summarize them by constructing two competing theoretical frameworks for the definition of good and bad governance. One is a framework of formalism and principles. In it, notions of 
good and bad governance tend to revolve around principles from which it is thought to derive good or bad consequences. For example, the formalism of Rothstein and Teorell (2008a, 2008b) indicates that foremost we should all be treated alike and expect to be so.

The second framework emphasizes consequences, which it treats as a function of context and culture and not just principles. This consequentialism may involve some greasing of palms to make things work and achieve a greater good than would have been achieved by strict adherence to formal principles. However, if we judge good and bad governance by its consequences, then perhaps there is no philosophical or legal way to ground it unless we define it by principle rather than consequence. The interesting thing about Rothstein and Teorell's (2008a, 2008b) project is that it investigates consequences empirically (for example, people's sense of fairness) and then reverts to a principle — that of equitable treatment. ${ }^{2}$

\title{
CONDITIONS OF GOOD AND BAD GOVERNANCE
}

\begin{abstract}
Although money politics-corruption and cronyism-is generally seen as inhibiting economic growth, there are certain conditions in which it can actually be beneficial. Developing countries typically have weak institutional structures.
\end{abstract}

2. In this theoretical framework, we can identify two opposing definitions of good governance: one (liberal, western, and democratic) stresses protection of human rights and free choice, and the other (authoritarian) stresses order and control maintained by a single party. Between these two opposites is a whole continuum of beliefs and values. Another continuum focuses on a wider notion of governance, taking into account relations between societies. On one end is the notion of a flat world, in which states have been marginalized in many ways and a key aspect is freedom to move, trade, and share ideas. On the other end is the notion of a world of distinct nation-states that trade freely but also defend their own economic and geopolitical interests. The former view supports international interventions, including in the domestic affairs of other countries, to ensure basic rights and freedoms and support liberal values (the United States is one example); the latter view may support minimal intervention in other societies while protecting national interests (China is one example). Various factors can help explain the choices different countries and organizations make within these continuums. Most start with an assumption of what good and bad governance consist of. The World Bank governance indicators mentioned earlier, for example, assume the values of liberal western democracy and a flat world. Scholars in China, in contrast, would focus on solidarity, stability, and control. Discussing the differences between these assumptions and values would be an important contribution to the understanding of good and bad governance. 
In that case, if there is a balance of power among a small and stable set of government and business elites, money politics can actually reduce transaction costs and make long-term agreements and investments more efficient, even while enriching those fortunate few who collude together.

Kang, 2002, p. 3

\section{Stages of Development and Institutions}

Conditions involve stages of development. The early stages of development are rarely pretty. They often involve the social and physical displacement of people, excesses of pollution, and environmental ruination. But if successful, development also leads to attitudes that are typically more favorable to social amelioration, environmentally friendly policies, and other improvements.

Conditions, of course, have a lot to do with the quality of governance in different stages of development (Rothstein \& Teorell, 2008a). Governments that are hard pressed to pay their officials a decent salary can expect corruption, bribery, and the like, and they may also find their officials moonlighting (working at other jobs). This is no doubt a common malady of the less developed world.

Conditions also include, among other things, institutions which provide inducements to behavior that may have either positive or negative externalities and that may make it more (or less) difficult to arrive at solutions, to make (or not make) fiscally responsive policy, or to impose short-term costs for long-term gain. Institutions also may be more or less democratic. Voting systems and systems of representation may be more or less reflective of popular sentiment. Plurality systems sometimes waste and distort votes, displace more complex sentiments in the public with more extreme outlooks of party elites, and produce, in the end, leadership that is likely to be stronger but also more unrepresentative. Proportional representation systems mainly do the opposite, but often suffer from a lessened ability to govern.

\section{Quality of Government}

Considering the importance of conditions such as stages of development and democratic consolidation and degree of corruption, the quality-of-government study of Rothstein and Teorell (2008a, 2008b) has reported that the "expectation of fair and equal treatment" by authorities is highly robust—an especially critical finding for societies that are ethnically, linguistically, religiously, and racially diverse. The expectation of fairness builds confidence. But what exactly does it mean to be fair? Fairness means that each person is treated and responded to the same way. 
However, what Rothstein and Teorell (2008a, 2008b) have actually described is fairness in a formal sense, implying that justice is blind. What then about compensatory measures to deal with past inequities, for example affirmative action? Regardless of the virtue or value of such compensatory measures, they are bound to create some perception, and probably reality, of unfairness and inequity on the part of those adversely affected. In the United States, those happen largely to be Caucasian males, but these measures also adversely affect many people of Asian extraction because Americans of Asian extraction tend to be a high-achieving and high-income-earning group.

Inevitably, the question has been debated as to whether fairness and equity are individually or collectively relevant or both, and whether programs that begin as compensatory measures degenerate over time and displace their original if quite open-ended purpose of rectifying past injustices. Obviously, if one can make this much fuss about one idea, such as fairness and equity, imagine what it is like to do the same for the wide array of concepts that figure into good and bad governance. ${ }^{3}$ In other words, context does count, and the discrete nature of good or bad likely has to be replaced by a continuous measurement.

\section{Trade-Offs between Highly Desirable Goals}

Trade-offs between highly desirable goals, as Wilson (2008) indicates, are inevitable. Almost every value that we like has a downside. In the United States, it is often said that its government is a government of laws, not of people. A government of laws implies that rules are important and constitutionality is vital (Rosenbloom \& Piotrowski, 2005). It also implies that laws are arrived at through a defined process. Moreover, lawful processes imply equal treatment.

However, laws without compassion, sympathy, or flexibility are the kind that Charles Dickens had in mind when he had a character say "the law is an ass." Lawfulness

3. US Supreme Court Justice Potter Stewart once said famously that while he could not define pornography, he knew it when he saw it. Based on a similar "sniff test" of good and bad government, do Sweden and Norway have good government or bad? How about Zimbabwe and Myanmar? These are easy questions to answer. Almost anybody would say that Sweden and Norway are governed well and Zimbabwe and Myanmar are governed horrendously. The government of Turkey or Israel would probably not look very good compared to that of Germany or France-Turkey because its military has such a powerful role and Israel because of its political fragmentation and its professionalization of politics but not of governance. But compared with neighbors such as Egypt and Syria, Turkey and Israel would look a lot better. 
implies equal opportunity to set the rules, to adjust them, and to take due account of the rights of minorities. There is, to be sure, a distinction between "lawfulness" and legal edicts. Legal edicts, after all, were used in Nazi Germany, South Africa, and the United States to repress the rights of distinct populations, and they were put to use by the last Bush administration to sabotage the American Constitution, the legal system, and longstanding international agreements to which the United States has been a signatory.

It can also happen that things we don't like, such as corruption or authoritarianism, can bring benefits. The World Bank objects to corruption because it hurts the poor most. For the most part, it is justified in doing so when all corruption does is enrich oligarchs. In other instances, some measure of corruption may facilitate flows of capital and decrease transaction costs, especially in the take-off stages of growth. Kang (2002) argues that crony capitalism worked to speed development in South Korea but failed in the Philippines. Moreover, he argues that conditions of crony capitalism can differentiate South Korea and the Philippines while also bridging the boom years and the crisis. To understand the contrasting economic outcomes of crony capitalism in South Korea and the Philippines, one must directly address conditions of corruption and politics there.

Similarly, with regard to authoritarianism, there are different varieties-for example, Singapore and North Korea. Most of the Asian tigers built the basis for the modern economies that sustain their current democracies while under authoritarian rule (Hahm $\&$ Heo, 2008). Perhaps we ought not to be excessively judgmental about democracy before the conditions for democracy ripen (Rosenbloom \& Hahm, 2010; Whitford \& Lee, 2009). With respect to developmental conditions, while the affluent democracies sought to circumvent the Weberian model, in poor countries such as Bangladesh, the goal was to get these countries to the Weberian model of predictability and regularity. ${ }^{4}$

As abstractions, the virtues of impartiality, legality tempered by compassion or common sense, representativeness, regard for the opinions and interests of others, freedom and regard for the public good, economic growth, concern for the future, and concern for excesses of inequality are not controversial. The difficulty is how tradeoffs may be made between them, because such trade-offs must inevitably be made.

4. The discussion of governance conditions could focus on what similarities and differences among countries go along with differing forms of governance. For example, rich countries tend to have liberal, democratic, flat-world outcomes, with partial exceptions like Singapore, and vice versa. Corrupt states tend to be poor, and vice versa, again with exceptions like rich but corrupt Italy. However, there is no proof we know of as to whether governance conditions (such as freedom from corruption) lead to wealth, or whether wealth leads to better governance conditions. 
Why do some governments make these trades in one way rather than another? This is directly related to consequences of good and bad governance.

\section{CONSEQUENCES OF GOOD AND BAD GOVERNANCE}

Consequences presume, by definition, that a consequentialist moral theory is the sole basis upon which to judge good and bad governance. This is an important point, incidentally, connected to issues of development.

\section{Importance of Institutions}

Can good government create a good society? Or will a good society inspire good government? Are all of these things hopelessly embedded and enmeshed? For example, think of China a mere 30 years ago. It is easy to disagree with its form of governance, though it is far better today than it was then. Even though China's current form of governance is imperfect, it is difficult to assert that it is not being governed well. Perhaps, however, there are more complaints in countries with long-established constitutional systems than in countries just emerging in that direction, simply because expectations are higher in the older systems.

In this regard, as noted earlier, institutions are very important in many ways. Among other things, they provide inducements to free-riding or to credible commitments. Much of the institutional literature on federalism focuses on the structure of transactions and commitments between levels of government as regards their financing obligations. We have also noted how some forms of voting lead to a high prospect of significantly unrepresentative outcomes.

In the United States, for example, a distorting plurality system is exacerbated by an institution such as the Senate that gives equal representation to political units of highly divergent sizes, creating a body in which the proportion of the overall party vote for the Senate bears little resemblance to the outcome of seats in the chamber. To distort matters even further, in presidential elections it is the electoral college that actually elects the president, and not the popular vote.

The electoral college is composed of electors from each state equal in number to the number of that state's representatives in the House of Representatives (which can vary) and in the Senate (which is always two), plus three electors from the District of Columbia. Except for two states that divide their vote by congressional district, each state's vote goes entirely to the plurality winner in that state. The results are massively distorting. Typically, the electoral college system gives the winner the 
illusion of a larger claim than is warranted by the popular vote. In narrower elections, the electoral college has voted against the winner of the popular vote about 11 percent of the time. Can such a system plausibly be called democratic? Or representative? Thus, institutions alone guarantee nothing, especially in the face of powerful preferences or circumstances.

\section{Importance of Social Differences}

There is a growing but also conflicting literature on the role of social cohesion and social difference in social and economic development. Societies with a high degree of social homogeneity seem to be more collectively oriented, more likely to support their fellow citizens, and more likely to generate social capital. That seems to be true enough. However, Page (2007) notes that creative outcomes are more likely to be the product of social difference. In particular, he argues that progress and innovation may depend less on lone thinkers with enormous IQs in a society with a high degree of social homogeneity than on diverse people working together and capitalizing on their individuality.

In this regard, Florida $(2002,2005,2008)$ argues that the creative class flocks to centers of diversity and cosmopolitanism and innovation, even to avant garde lifestyles. In so doing, it reinforces the energy there and becomes a powerful engine for growth and wealth. Conversely, locales where homogeneity prevails become more difficult for outsiders to break into, attract fewer outsiders, and tend to resist change. At the same time, they often have high levels of social capital and communal cohesion because, after all, everyone is expected to share similar tastes and loyalties. There is a more powerful sense of social appropriateness. But it is conceivable that social capital and the creation of financial capital may be at odds with one another. Gemeinschaft and Gesellschaft each have their virtues and faults, but it may be extremely difficult to reinforce their virtues - which, of course, if achievable, would be an optimal outcome.

\section{Importance of Political Leadership at the Top}

We now realize that government exists in a governance system that is increasingly interdependent (Kettl, 1995, pp. 27, 39). In particular, we engage in a market-based system in which the government is simply one player at the table along with everyone else. Our concerns about the quality of government, as Kettl (1995, pp. 37-38) indicates, stand out most clearly when government encounters its citizens through bureaucrats.

However, we still have an authority-based, rule-based, and hierarchical government encountering a market-based system of private contractors and citizens. Government 
is a law-driven, rule-based entity, and its responsibility is to administer the law, according to standards of due process and procedure that guarantee equal treatment and protection. In contrast, the market is a customer-based entity and its main concern is the efficiency of its transactions. These two sectors - an authority-based government and an exchange-based market - collide most sharply at the point where government meets its citizens. Moreover, when these two sectors interact, competing expectations on complicated social issues produce fundamental problems of legitimacy in the quality of government.

In this regard, one solution is to recognize that there are many players and a plurality of interests. Government should not be able to exclude particular groups; anyone who has an interest has a right to sit at the table (the so-called seat-at-the-table issue). Government must also ensure that the people seated at the table have some feeling of participation in the process (the so-called hand-on-the-switch issue). There must be some connection between being able to sit at the table and being able to do something (Kettle, 1995, p. 39). In this new environment, as Kettl (1995, p. 39) and Wilson (2008) have noted, there is a need for political leadership to deal with these issues. Specifically, we first have to be certain that the top-level government leadership makes these seat-at-the-table and hand-on-the-switch issues work. Second, we have to ensure that the top leaders in the government fulfill that responsibility, but fulfillment will only occur when they spend their time leading and engaging these issues.

Furthermore, as Kettl (1995, pp. 39-40) notes, we need to recognize the importance of law, procedure, due process, government red tape, and all such things about which we complain against government. They exist because we expect government to differ from the market; we expect it to provide due process and equity and to engage us in a way that is fair. In this environment, the paramount problem is how to guarantee, when everyone has a hand on the switch, that in the end it is law that rules, not private interest-how to ensure that the public interest dominates.

In the end, the solution will be a system that deals with the relationship between government and its citizens through bureaucrats, but that relationship can work well only if it is structured clearly by political leaders at the top. Therefore, it is crucial to governance to build up what Dror (2000) calls "the brain of government" - if that is at all possible, recognizing how difficult it is in countries that are poor or enmeshed in turmoil, violence, or religiously inspired ideologies. Finer (1980) thinks of this as the "futurity principle" - the ability of government to think about the future analytically and by understanding the past. Unfortunately, it is not enough to have good wishes for the future without discernable means to affect it. Plausible tools are essential to capitalize on analytical and professional capabilities in order to achieve desirable futures or most likely merely to avoid very undesirable futures. No one can mandate outcomes. 


\section{CONCLUSION}

These arguments and considerations move us toward a deeper and broader understanding of the multiple meanings of good and bad governance. However, every rule, as Kaufman (1960) notes, produces rigidity and red tape. Obviously, or perhaps not so obviously, there is no single right answer. And what answer one gets depends upon who is asked and about what they are asked. In this regard, we all have different ideas of what really constitutes good and bad governance. Indeed, figuring out precisely what good and bad governance are turns out to be highly complex. But we must continue to evaluate claims empirically.

For example, Jones and Williams (2007), a political scientist and an economist, explore the so-called politics of bad ideas: why, over the last quarter century, bad economic ideas-such as cutting taxes without cutting spending-have become so influential in shaping government policies. Specifically, they examine empirically the remarkable claims made by the Bush administration about its 2001 and 2003 tax cuts. Contrary to the claimed results, they find that tax cuts yielded weak overall economic growth, rapidly rising national debt, falling housing prices and increasing foreclosures, and the widest disparities in income since the 1920s. In sum, our ideological tastes or illusions need to be tested. Knowledge is a vital precondition for good governance.

In the end, good and bad governance makes for a good (or bad) title. But the reality is that it is multidimensional, continuous rather than discrete, conditional, consequential, and empirical as well as philosophical. It is a complex and even mind-boggling business. And like anything that seems so imponderable, the first step is the reduction of all of this complexity in order to find irreducible core components. That is a good beginning in a venture that we suspect will have no end.

\section{REFERENCES}

Alesina, A., \& Angeletos, G.-M. 2005. Corruption, inequality, and fairness (NBER Working Paper No. 11399). Cambridge, MA: National Bureau of Economic Research.

Brewer, G. 2004. Does administrative reform improve bureaucratic performance? A cross-country empirical analysis. Public Finance and Management 4(3): 399428.

Brewer, G., Choi, Y., and Walker, R. 2007. Accountability, corruption, and government effectiveness in Asia: An exploration of World Bank governance indicators. International Public Management Review 8(2): 200-218. 
Dror, Y. 2000. The capacity to govern. London: Frank Cass.

Finer, S. E. 1980. Changing British party system. Washington, DC: American Enterprise Institute.

Florida, R. 2002. The rise of the creative class: And how it's transforming work, leisure, community, and everyday life. New York: Basic Books.

Florida, R. 2005. The flight of the creative class: The new global competition for talent. New York: HarperCollins.

Florida, R. 2008. Who's your city? How the creative economy is making where to live the most important decision of your life. New York: Basic Books.

Hahm, S. D., and Heo, U. 2008. US and Japanese foreign direct investment in East Asia: A comparative analysis. Policy Studies Journal 36(3): 385-401.

Helgesen, G., and Kim, U. 2000. Good government: Nordic and East Asian perspective. Copenhagen: Nordic Institute of Asian Studies.

Inglehart, R. 1971. The silent revolution in Europe: Intergenerational change in postindustrial societies. American Political Science Review 65(4): 991-1017.

Inglehart, R. 1977. The silent revolution: Changing values and political styles among western publics. Princeton: Princeton University Press.

Jones, B., and Williams, W. 2007. The politics of bad ideas: The great tax cut delusion and the decline of good government in America. New York: Longman.

Kang, D. 2002. Crony capitalism: Corruption and development in South Korea and the Philippines. Cambridge: Cambridge University Press.

Kaufmann, D., Kraay, A., and Mastruzzi, M. 2004. Governance matters III: Governance indicators for 1996-2002. Washington, DC: World Bank.

Kaufmann, D., Kraay, A., and Mastruzzi, M. 2006. Governance matters V: Aggregate and individual governance indicators for 1996-2005. Washington, DC: World Bank.

Kaufmann, H. 1960. The forest ranger: A study in administrative behavior. Baltimore: Johns Hopkins University.

Kettl, D. 1995. Governance. In K. Thompson (ed.), Governance (pp. 25-45). New York: University Press of America.

La Porta, R., Lopez-de-Silanes, F. Shleifer, A. \& Vishny, R. 1999. The quality of government. Journal of Law, Economics, and Organization 15(1): 222-279.

Longo, F. 2008. Quality of government? A theory of impartial government institutions. Governance 21(2): 165-190.

March, J., \& Olsen, J. 1989. Rediscovering institutions: The organizational basis of politics. New York: Basic Books.

Page, S. 2007. The difference: How the power of diversity creates better groups, firms, schools, and societies. Princeton: Princeton University Press. 
Peters, B. G. 2003, October. The capacity to govern: Moving back to the center? Paper presented at the VIII Congreso Internacional del CLAD sobre la Reforma del Estado y de la Administración Pública, Panama.

Peters, B. G., \& Pierre, J. 2002. Bureaucrats and administrative reform. London: Routledge.

Power, J. 2007, October. Responsible governance and constrained parliamentarism. Paper presented at the International Conference on Governance in Comparative Perspective, Seoul.

Rauch, J. E., \& Evans, P. 2000. Bureaucratic structure and bureaucratic performance in less developed countries. Journal of Public Economy 75(1): 49-71.

Rosenbloom, D. 1993. Have an administrative Rx? Don't forget the politics! Public Administration Review 53(6): 503-507.

Rosenbloom, D., \& Hahm, S. D. 2010. Public administrative theory, performance, and accountability: Problems and prospects in diverse political environments. Administration \& Society 42(1): 4-10.

Rosenbloom, D., Kravchuk, R., and Clerkin, R. 2009. Public administration: Understanding management, politics, and law in the public sector (7th ed.). New York: McGraw-Hill.

Rosenbloom, D., and Piotrowski, S. 2005. Outsourcing the constitution and administrative law norms. American Review of Public Administration 35(2): 103-121.

Rothstein, B., \& Teorell, J. 2008a. What is quality of government? A theory of impartial government institutions. Governance 21(2): 165-190.

Rothstein, B., \& Teorell, J. 2008b. Impartiality as a basic norm for the quality of government. Governance 21(2): 201-204.

Whitford, A., \& Lee, S. Y. 2009. The efficiency and inefficiency of democracy in making governments effective: Cross-national evidence. Paper presented at the annual meeting of the American Political Science Association, Toronto.

Wilson, G. 2008. Quality of government. Governance 21(2): 197-200.

Wong, W., and Welch, E. 2004. Does E-government promote accountability? A comparative analysis of website openness and government accountability. Governance 17(2): 275-297. 